\title{
Language Policies as an Instrument of Shaping and Rhetoricizing Mutual Relations in the Post-Soviet Region
}

\begin{abstract}
The post-Soviet region is inhabited by communities using a high number of languages and dialects. This linguistic mosaic has been formed for millennia. Very often it turned out to be a factor seriously influencing the development of the geopolitical situation in this part of the globe.

The post-Soviet region remains a space where language issues are still challenging and very sensitive. In large measure, traditional problems became more complicated during the period of the regional expansion of the Russian language in the nineteenth and twentieth centuries. Nowadays, states in the region try to create more or less autonomous language policies, sometimes calculated on relieving and sometimes on fueling socio-political conflicts. Language policies often turn out to be the instrument by which players in the region are trying to diminish or increase the gap in mutual relations. Additionally, political solutions applied to language issues often serve as a kind of argument in the axiological rivalry between communities living in the area of the former USSR.

The paper aims to analyze some selected aspects of these policies. It also tries to characterize in general their rhetorical qualities and argumentative potential.
\end{abstract}

Key words: Language policy, rhetorical aspects of language policy, the Post-Soviet Region, the specificity of language policies in the Post-Soviet Region

\section{Introduction}

C onsidering the language policies of the post-Soviet region as a separate subject of studies is not and cannot be an unquestionable procedure. Moreover, it should be regarded as requiring careful reflection and objectified justifications. In formulating them, one must, first of all, determine for which research purposes this procedure can be used as well as the achievement of which it may hinder. ${ }^{1}$

It seems that the study on language policies of the post-Soviet region could be carried out in order to grasp their specificity. However, this would entail an assumption that language policies in the post-Soviet states are somehow significantly different as compared to language policies from outside the former USSR. Such a starting point would inevitably affect the course of the research; in the light thereof, noticeable differences between the language policies implemented in the post-Soviet space and outside it might seem excessively deep and essential, whereas similarities - shallow and less important. From here it is but a short step to making hasty contrasts, unauthorized comparisons and creating beliefs about the superiority or inferiority of standards applicable inside or outside the post-Soviet world.

1 The term post-Soviet area was introduced into public discourse as a political concept by Prazauskas, who first used it in his text СНГ как постколониальное пространство (published in Независимая газета in 1992; Празаускас, 1992). 
Therefore, one may ask: is it at all reasonable to treat the post-Soviet space as a region, as well as to single out a group of language policies which have been formed there? After all, it has been more than a quarter century since the collapse of the USSR. During this time, states arising as a result of this process have developed side by side, sometimes choosing very different and often divergent, or even conflicting paths. Populations of these countries have discovered or created their uniqueness, sought to identify past prerequisites of their identity, and more or less intensively discussed their future, trying to determine priorities and determinants of their development and relations with others.

However, the nations living in this area are undoubtedly connected by their common, but often uneasy and tragic past, in particular the nearly 70-year history of the USSR, as well as stereotypes, habits of thought, schemes of socio-political practices - including patterns of thinking about languages and pursuing the language policy - shaped and propagated at that time. Hence one may risk saying that within the framework of political bodies created after 1991, all post-Soviet societies must and try to cope with their challenging but collective history. ${ }^{2}$

The prior reality undoubtedly influences a broad spectrum of sociolinguistic ideas and reflections which circulate in the post-Soviet space. ${ }^{3}$ This, inter alia, gives rise to a set of beliefs about what language in general is, as well as what forms and deforms it. These general imaginings provoke more detailed questions: whether specific languages spoken by inhabitants of the post-Soviet region are close or distant; which of them possibly support one another; which, if any, pose a threat to one another; how the hierarchy of these languages is formed; which are considered more or less prestigious and why. In short, language politics and policies in the post-Soviet space, as well as ideas, expectations, dreams, and fears spread there, can be treated as an arrangement of mutual references, elements of which are linked to each other by strong and deep, though often very imperceptible, relations. Of course, studying this wholeness, we should remember the fact that the post-Soviet region is not currently separated by some invisible wall from the rest of the world. Linguistic communities existing there affect not only each other but also intensively deal with language phenomena from outside the area of former USSR.

\section{The rhetorical approach within the field of studies on politics of language, and language policies in the post-Soviet region}

Referring to the title of the paper, the issue of rhetoricizing mutual relations between entities from the post-Soviet region is not indisputable either. Stressing it means a willingness to analyze and evaluate post-Soviet language practices and related discourses with the use of categories derived from the tremendously vibrant field of rhetoric theory. Thus, it seems reasonable to pose a question of what can be gained using such an approach.

${ }^{2}$ Among recent publications in this filed see e.g. Isaacs, Polese, 2016. On the issue of the earlier than the Soviet, strongly complicated and competitive coexistence of some nations inhabiting the postUSRR area today, see Cywiński 2013.

${ }^{3}$ About the importance of the past in the processes of language regimes emerging and lasting, as well as about difficulties and opportunities associated with the conceptualization of this field of studies, see Cardinal, Sonntag, 2015, pp. 3-26; Shiffman, 1998. 
Rhetoric has often been perceived as the art of persuasion and its claim to universalism has been founded on the belief that each message is in some way more or less persuasive; it carries persuasion directly or at least anticipates it, creating circumstances for direct convincing. It is also essential that the importance of taking into account the fact that people have different tastes and preferences has been emphasized in the space of rhetorical thought since antiquity. This supported the conclusion that people's views are conditioned by their particularistic axiologies, which should be realized if one wants to get someone to do something (Burke, 1969; Lausberg, 1998; Lichański, 2007; Volkmann 1995; Ziomek, 1990; Worthwington, 2010; Perelman, 2002). The idea seems to be respected by Aristotle when he says that "[r]hetoric then may be defined as the faculty of discovering the possible means of persuasion in reference to any subject whatever" (Aristot. Rh. 1.2.1). At the same time, rhetorical tradition has often been considered as convincing others what is appropriate. Thus the principle of appropriateness, using it as a basis to practice reflection on the text, seems to be a fundamental discovery of rhetoric and its most serious advantage. The principle of appropriateness refers in fact to the principle of courtesy and this is associated consistently with the general formula of justice, which is well known, say, from Plato's Politeia. According to this formula - to recall something that seems so well recognized but is often overlooked - everyone should do what they are supposed to do, which is consistent with their predispositions (nature) and dispositions (character).

Moreover, when speaking of the rhetorical tradition, attention is given to the areas of human thought that have developed over several thousand years and remain alive. For some reasons, the fact which seems especially important is that rhetoric has been developed for so long that its history is a common heritage of a high number of cultures. This heritage, what is noteworthy, generally stays older than political and social differences and divisions essential from the contemporary point of view (rhetoric is for instance almost as old as Judaism, being significantly ahead of Christianity and Islam in the chronology of events). The tradition of rhetoric can, therefore, be referred to as a common core, instead of, for example, uncomfortable, embarrassing and very often awkward religious or nationality comparisons. Thus, by embedding research into a political and legal text in the framework of rhetorical tradition, it is possible to obtain a widespread, supraregional ground to speak about communication and interpretation. Furthermore, it is not a basis, the adoption of which would lead to excessive universalization and schematization of socio-political knowledge. Anchoring studies on a specific text in the rhetorical tradition not only does not require but also does not allow its historical or cultural background to be ignored. Without taking into account the traditions and peculiarities of the time and place at which a message is created or received, it is not possible to understand the motivations and persuasive purposes of its author.

When adopting all of the above assumptions, it should be said that language policies (including those present in the post-Soviet region) may be treated as a kind of persuasive activities. In consequence, it should be assumed that states and other entities involved in creating and pursuing these policies are well aware that they are related to very delicate issues connected with the sense of pride of various communities, as well as the sense of their dignity, security, their fears and hopes, and the sense of inclusion or exclusion. It is also generally known that both the language policy itself and its presentation strongly 
influence the international image of their implementers and may bring the others' respect or contempt, gratitude or resentment.

For this reason, an issue which seems particularly interesting is how the creators of language policies in the post-Soviet region are trying to present and justify their activities - what seems to be convincing to them in this respect. Therefore, a set of fundamental questions determining reflection in this text is as follows:

1. How has the rhetorical dimension of discourse on language policies been shaped in the post-Soviet space?

2. How do the creators of language policies in the post-Soviet region try to present and characterize their practices - as preventing risks and solving problems or as creating and using opportunities generated by languages?

3. Do the creators of language policies in the post-Soviet region try to oppose their language policy to other language policies? If so, how do they define the essence of the dispute or disputes between supporters of these or other solutions?

4. Are the creators of language policies in the post-Soviet space eager to motivate them by striving to protect any language against the impact of other languages?

5. Are the creators of language policies in the post-Soviet space eager to motivate their activity by the conviction that linguistic pluralism gives chances for development and quality enrichment of all languages subject to the mixing processes?

6. Do the creators of language policies in the post-Soviet region characterize languages as separate systems, having somehow clearly defined boundaries, or as dim entities, strongly intertwined and intensely interpenetrating?

\section{Analyzing rhetorical aspects of language policies in post-Soviet space - samples for exploration}

The following part of the paper is divided into two sections. The first section discusses views on language and language policy presented during a joint meeting of the Council for Interethnic Relations (Совет по межнациональнымм отношениям) and the Council for the Russian Language (Совет по русскому языку), which took place on May 19, 2015 (Совместное заседание). The meeting was chaired by the Russian President Vladimir Putin. It can be regarded as an event during which views on the federal language policy were formulated and expressed by people seriously engaged in designing and implementing it. Therefore, materials from this meeting should be seen as a significant source for determining patterns to justify the language policy currently favored by the Kremlin elites. The manner of speaking, arguments cited and a form of expressing them say a lot about what the official creators and influential interpretations of federal and regional language policies declare today, and what statements they consider convincing in this regard.

Secondly, the text entitled Language Policy in Ukraine: past debates and future solutions by Mykola Riabchuk will be discussed (Riabczuk, 2015, pp. 301-321). This material in principle collects and presents in great detail all the most considerable argumentative potential that can be currently observed among advocates for increased protection of the Ukrainian language in Ukraine. At the same time, Riabchuk's views on language 
issues should be considered as very strong, not to say radical. However, these strong views clearly reveal a possibility of rhetoricizing post-Soviet - in this case, the Ukrainian - reality by references to the language issue and the assessment of policy options associated therewith.

These materials, namely the Transcript of the Meeting, as well as the text by Mykola Riabchuk, were chosen primarily due to their argumentative qualities. Arguments presented in the two texts make it possible to figure out how choices regarding language policy in the post-Soviet region can be made, how the language policy can be justified, and how it can be highlighted to create someone's positive or negative image. In short, a careful analysis of these materials gives a picture of what can be described as rhetorical exploitation of the potential of language policies in the territories formerly belonging to the USSR.

It should also be noted that messages from the Russian Federation and the Ukrainian Republic were not accidentally selected. Radical deterioration of relations between the two entities, as well as the unresolved issue of the status of the Russian language in Ukraine, are factors that result, inter alia, in reflection and argumentation on language issues in these countries dynamically developing at present. There is no doubt that other countries of the post-Soviet region are observing the evolution of language policies of both Russia and Ukraine carefully. A sort of confrontation of these policies certainly gives them material for thought and turns out to be an essential factor that determines the whole regions thinking regarding:

1) what and for whom a given language is,

2) what its relations with other languages are, and finally,

3) what the language policy is, what can and should be the principles thereof, and what goals can be accomplished with its help.

\subsection{Rhetorical perspectives of the Russian language policy (Transcript of the Meeting)}

When reading the Transcript of the Meeting, it can be seen that both the President of the Russian Federation and other speakers stressed in particular that the language policy is not important in itself. The tendency referred to is well reflected in a short description of the meeting published on the presidential website: "The meeting was devoted to the role of the Russian language and the languages of the peoples of Russia in strengthening statehood, improving actions for the preservation and development of national languages. ${ }^{.4}$ The characteristics cited seem to reveal in the first instance that authorities deal with the issue of language because they are interested in the role that the language policy can play in strengthening statehood. Therefore statehood is shown as an autotelic value which can be strengthened or weakened by language policy. Only then is attention given to the fact that the meeting was also organized to discuss the issues of preservation and development of national languages. What is important, first and the foremost emphasis is laid on the "preservation" and only then is the "development" also mentioned.

${ }^{4}$ In Russian: “'Заседание посвящено роли русского языка и языков народов России в укреплении государственности, совершенствованию мер по сохранению и развитию национальных языков" (Совместное заседание). 
The case is similar as regards the President's speech, who began the meeting by stating that participants will be reflecting upon the "issues of protection and development of the Russian language," as well as all the languages of the peoples of Russia. He also stressed that these issues "are essential for harmonization of relations between ethnic groups, ensuring citizens' unity, strengthening the sovereignty and integrity of Russia." 5

The presentation of the language policy of the Russian Federation was used by Vladimir Putin to promote the theory according to which the state is looking for a balance between the needs of the entire nation and the needs of linguistic minorities. In his opinion, "balanced language policy" for multi-ethnical, multi-religious and multi-lingual Russian Federation "is certainly one of the obvious priorities" (Совместное заседание). The balance referred to should also "protect traditional values" as well as "avoid self-isolation from global cultural processes." ${ }^{.6}$ According to the Russian President, it should be remembered at the same time that contemporary language space is formed by the media, which "more and more often violate the rules of language and elementary accuracy, using unwarranted, clearly unnecessary foreign borrowings." "

Moreover, according to Putin, one should understand that "[f]or every nation, the problem of preservation of the mother tongue is the problem of preserving identity, originality, and tradition." ${ }^{8}$ In his view, the unity of Russia depends directly on the knowledge of the Russian language among young citizens of the Russian Federation. It is so because "the Russian language, along with the culture, has created Russia as one multinational civilization, has ensured over the centuries connectivity of generations, continuity and mutual enrichment of ethnic cultures."

At the same time, Putin considered it essential to clearly and repeatedly stress that the language policy pursued by Russian authorities respects the rights of individuals and linguistic minorities. He pointed out that "[t]he Russian Constitution explicitly guarantees the right of all nations to protect their native language, to create conditions for its learning and development." ${ }^{10}$ In particular, according to him, "republics have the right

${ }^{5}$ In Russian: “Вопросы сохранения и развития русского, всех языков народов нашей страны имеют важнейшее значение для гармонизации межнациональных отношений, обеспечения гражданского единства, укрепления государственного суверенитета и целостности России" (Совместное заседание).

${ }^{6}$ The entire phrase in Russian reads as follows: “Да, конечно, глобальное информационное пространство сейчас формируется по известным правилам, общемировым правилам, всё это вносит в эту сферу объективные изменения - это всё понятно. Но, решая эти проблемы, конечно, важно соблюсти чёткий баланс. С одной стороны, сохранить традиционные ценности, самобытность, а с другой - не допустить самоизоляции от мировых культурных процессов" (Совместное заседание).

7 In Russian: “Сейчас её формируют прежде всего СМИ, интернет, телевидение, где всё чаще нарушают языковые нормы, элементарную грамотность, используют необоснованные, явно избыточные иностранные заимствования " (Совместное заседание).

${ }^{8}$ In Russian: “Для каждого народа вопрос сохранения родного языка - это вопрос сохранения идентичности, самобытности и традиций ” (Совместное заседание).

9 In Russian: “Именно он, русский язык, по сути, вместе с культурой сформировал Россию как единую и многонациональную цивилизацию, на протяжении веков обеспечивал связь поколений, преемственность и взаимообогащение этнических культур" (Совместное заседание).

${ }^{10}$ In Russian: "Конституция России прямо гарантирует право всех народов на сохранение родного языка, создание условий для его изучения и развития” (Совместное заседание). 
to establish their official languages and use them in the work of state authorities and local government at an equal level with the state language of Russia." ${ }^{11}$ Moreover, in light of the comments by Putin, "[c]hildren and their parents have the right guaranteed by the Constitution to freely choose the language of instruction," while "administrations of schools and regional authorities are required to protect this right." ${ }^{\prime 2}$ Importantly, the President of the Russian Federation did not miss the chance to characterize the right to learn the Russian language as an excellent opportunity for all, claiming that the past has shown that knowledge of this language "opened to representatives of any nationality greater opportunities for self-realization, education and achievement of professional success." $" 13$

Putin also noted that several languages of small nations living in Russia gained a written form only in the times of the USSR "owing to efforts of prominent Russian scientists, linguists, and philologists." ${ }^{14}$ Moreover, in his opinion, a beneficial effect on the development of these languages was first exerted by the Soviet, and currently the Russian policy in the field of translations of native works into Russian. Hence, according to Putin's claim, no one in the world has ever provided support for languages of small nations similar to that of Soviets or Russians. ${ }^{15}$

The Russian President also described the main features of faulty language policy. It happens, according to him, when authorities ignore citizens' needs in language matters, and the majority seek a "linguistic assimilation" of minorities. It is followed by the division into "fully-fledged and not fully-fledged people, into citizens and non-citizens" which leads "to direct, tragic internal conflicts." 16

Ideas and arguments of the other participants to the discussion in question generally harmonize with the presidential vision and the image of the Russian language policy. First of all, several statements affirm the Russian language, emphasizing a commitment to it and conviction of its strength. According to Alexander Mikhailovich Moldovan (the

${ }^{11}$ In Russian: “республики вправе устанавливать свои государственные языки и использовать их в работе органов государственной власти и местного самоуправления наряду сгосударственным языком России" (Совместное заседание).

12 In Russian: “Дети и их родители имеют гарантированное Конституцией право на свободный выбор языка обучения”; “администрации школ, власти региона это право обязаны обеспечить” (Совместное заседание).

13 In Russian: “Свободное, грамотное владение русским языком открывало для представителей любой национальности больше возможностей для самореализации, для образования, для достижения профессионального успеха" (Совместное заседание).

${ }^{14}$ In Russian: "Здесь отмечу, что письменность для многих языков была разработана лишь в советское время силами выдающихся русских учёных, лингвистов, филологов" (Совместное заседание).

15 In Russian: "Без всякого преувеличения можно сказать: подобной поддержки, настоящего сбережения национальных языков, как в нашей стране, никто никогда в мире не обеспечивал" (Совместное заседание).

${ }^{16}$ The entire phrase in Russian reads as follows: "Но мы знаем и другие примеры, когда в ряде стран право значительных этнических общин на использование родного языка игнорируется или ограничивается, когда проводится жёсткая, агрессивная политика языковой и культурной ассимиляции. И мы видим, к каким последствиям это приводит: к разделению общества на «полноценных» и «неполноценных» людей, на «граждан» и «неграждан», а то и к прямым, трагическим внутренним конфликтам" (Совместное заседание). 
Russian Language Institute of the Russian Academy of Sciences), "the Russian language has undeniable advantages, which can be discussed at length. In particular, according to the opinion of the academic Likhachov, this is one of the most perfect languages in the world, the language which has a thousand-year tradition of writing, with great classical literature which has introduced it to the group of languages that enjoy the greatest authority and are the most widely taught in the world." ${ }^{17}$ At the same time, according to Vladimir Tolstoy, "[t]he wealth of the Russian language gives inexhaustible possibilities; it is a gold supply which must be appreciated with dignity and by all means, protected. The higher the level of knowledge and use of the language by the society, the higher the culture of speech, the more powerful the intellectual level of the nation, its growth potential. ${ }^{\prime 18}$ According to the speaker, the Russian language, as well as the Russian culture, should be seen as the "main instruments of soft power, spreading, influencing and creating a favorable image of Russia, our great Motherland." 19 Tolstoy also pointed out that "the Russian language and the Russian culture unite multinational Russian society;" on the basis thereof "self-determination of citizens" is formed, owing to which every Russian may grasp "their allegiance to Russia, to the Russian world." ${ }^{20}$ On the other hand, according to Lyudmila Koltsova, "[t]he Russian language is a language not only of great literature but also of great science." ${ }^{21}$ Finally, according to Ivan Volgin, "in Old Slavonic, the word nation (народ) and the word language (язык) were synonymous, which means that when we talk about preserving the language, we actually talk about preserving the nation." 22

A lot was said of the need for the protection that federal and regional authorities should ensure for indigenous languages of various nationalities living in Russia. Peter Tultayev from the Association of Finno-Ugric Peoples of the Russian Federation claimed that the "inter-ethnic agreement, the fruitfulness of inter-nationality dialogue,

${ }^{17}$ In Russian: “русский язык обладает неоспоримыми преимуществами, о которых можно было бы много говорить. В частности, по выражению академика Лихачёва, это один из совершеннейших языков мира, язык с тысячелетней письменностью, с великой классической литературой, которая вывела его в число наиболее авторитетных и изучаемых в мире" (Совместное заседание).

18 In Russian: “Богатство русского языка, его неисчерпаемые возможности - это золотой запас, который необходимо по достоинству ценить и всемерно оберегать. Чем выше уровень знаний и использования языка в обществе, чем выше культура речи, тем мощнее интеллектуальный уровень нации, потенциал ее развития" (Совместное заседание).

19 In Russian: “язык и культура, безусловно, главные инструменты «мягкой силы», распространения, влияния и создания благоприятного образа России - нашей великой Родины” (Совместное заседание).

${ }^{20}$ The entire phrase in Russian reads as follows: "В то же время никогда нельзя забывать: единым многонациональный народ России делает русский язык, русская культура, именно они соединяют все сущие в ней языки, формируют наше гражданское самоопределение, позволяют каждому из нас ощутить свою принадлежность России, русскому миру" (Совместное заседание).

${ }^{21}$ In Russian: "Русский язык - это не только язык великой литературы, это язык великой науки" (Совместное заседание).

${ }^{22}$ In Russian: “в старославянском языке слово «народ» и слово «язык» синонимичны, то есть фактически речь идёт о сбережении народа, когда мы говорим о сбережении языка” (Совместное заседание). 
and the equality of the development of the culture of the peoples of the Russian Federation" depend on the solution to the issue of the "preservation and further development of indigenous languages and literature." ${ }^{23}$ In turn, Gulvayra Kutsenko pointed out that "the issues of protection of indigenous languages of small nations are the priority" since "[k]nowledge of the native language and using it is conducive to the formation of national self-consciousness and the strengthening of ethnic identity." ${ }^{24}$

Interestingly, some discussants concluded that it is also essential to develop the issues of importance of national languages in the context of globalization and intensification of international ties. According to Tolstoy, in recent decades, it has been seen that "the importance of national languages and cultures as the core values of every nation increases." ${ }^{25}$ Meanwhile, Ludmila Verbitska concluded: "We all understand well that the unique character of the Russian language, the language that is amazing, heroic, sensual and very susceptible to changes, easily interacting with other language practices, which gives great possibilities to express the most complex ideas, indeed makes it a tool for integration in the contemporary multicultural world." And further: "the issue of the Russian language is a security issue of our great Motherland." ${ }^{\prime 26}$

At the same time, there were also opinions that the contemporary Russians often have to choose whether their children should spend more time learning the Russian language or foreign languages (for example Alina Levitskaya; Совместное заседание). Finally, even a statement was formulated that the number of hours devoted to foreign languages is increasing at the expense of teaching the Russian language (Ludmila Dudova; Совместное заседание).

\subsection{Rhetorical perspectives of the Ukrainian language policy (Mykola Riabchuk)}

Mykola Riabchuk (born in 1953) is a Ukrainian poet, novelist, critic and political scientist. His views on language policy presented in the analyzed text can be regarded in their theoretical orientation as convergent with the attitude advocated by the current Ukrainian authorities (Riabczuk, 2015, pp. 301-321; Cf. Марусик). It seems that these

${ }^{23}$ In Russian: "Важность проблемы сохранения и дальнейшего развития родных языков и литературы заключается в первуюо чередь в том, что от её решения зависит во многом состояние межэтнического согласия, плодотворность межнационального диалога и равноправие развития культуры народов Российской Федерации " (Совместное заседание).

${ }^{24}$ In Russian: "Знание родного языка и владение им способствует формированию национального самосознания и усилению этнической идентичности. По этой причине вопросы сохранения языков коренных малочисленных народов являются приоритетными" (Совместное заседание).

25 The entire phrase in Russian reads as follows: “События последних десятилетий убедительно показали, что экономическая и финансовая глобализация в масштабах всего мирового сообщества только усиливает значение национальных языков и культур как главных ценностей каждого народа" (Совместное заседание).

${ }^{26}$ In Russian: "Мы все хорошо понимаем, что уникальная природа русского языка - языка удивительного, подвижного, чувственного и очень чувствительного к переменам, легко взаимодействующего с другими языковыми практиками, имеющего большие возможности для выражения самой сложной идеи - действительно делает его инструментом объединения в современном поликультурном мире" (Совместное заседание). 
views are also shared by a significant part of Ukrainian society ${ }^{27}$ and, in many respects, should be considered as clearly radicalized and highly persuasive. A part of Ukrainian academic discourse is visibly in line with them, which, according to Ryszard Kupidura, does not shun sharp arguments, both in content and in form. For example, Ukrainian researchers often represent an opinion that firstly the Russian and then Soviet policy should be regarded not only as a long-term promotion of the Russian language but above all as linguicide of the Ukrainian language. ${ }^{28}$

In his text, Riabczuk attempts to, inter alia, justify the theory according to which the language policy remains one of the natural areas of the state activity. He says that "[e]ach state implements a particular language policy, even if it does not formally articulate its principles and does not implement them as appropriate legislation, programs or projects, or - as the United States over almost the entire last century - officially adheres to a policy of no interference (laissez-faire) in the language processes. Yet language policy in the broad sense means not only a system of measures aimed at supporting one (or more) languages and respectively non-supporting, or marginalizing, and sometimes prohibiting other languages. Language policy also means selection of such and no other standard of the national language (or languages), improving spelling, publishing dictionaries, discussing and introducing new terms, learning and using foreign languages, translation of literature, scientific and technical texts, legal documentation, etc. Therefore, even mono-ethnic and monolingual countries which in today's world are rather rare, also implement a certain language policy - regardless of whether they call their actions (or lack of actions) policy." 29

At the same time, the author of the analyzed text argues that the construction of Ukrainian identity sometimes requires decisive choices based on different standards than

${ }^{27} \mathrm{Cf}$. results of the Ukrainian public opinion surveys; although being part of the current political discourse, they should be treated with a great deal of caution e. g. Отнотение к статусу.

${ }^{28}$ As Kupidura states, "[a]ccording to the well-known Finnish linguist and pedagogue Tove Skutnabb-Kangas, this term denotes a kind of discrimination based on language, as well as an ideological attitude and socio-political practice aimed at conscious and consistent reduction of language rights, leading eventually to the destruction of language as the main feature of a nation or ethnic group" (in Polish: "Według znanej fińskiej lingwistki i pedagożki Tove Skutanbb-Kangas termin ten oznacza rodzaj dyskryminacji ze względu na język, a także postawę ideologiczną i praktykę społecznopolityczną, mającą na celu świadome i konsekwentne ograniczanie praw językowych, prowadzącą ostatecznie do wyniszczenia języka jako głównej cechy danego narodu lub grupy etnicznej”; Kupidura, 2015, p. 288).

${ }^{29}$ In Polish (which is the language of the analyzed publication): "Każde państwo realizuje pewną politykę językową, nawet jeśli formalnie nie artykułuje jej zasad i nie wdraża ich formie odpowiednich aktów prawnych, programów czy przedsięwzięć albo - tak jak Stany Zjednoczone w ciągu niemal całego minionego stulecia - oficjalnie wyznaje politykę braku ingerencji (laissezfaire) w procesy językowe. Przecież polityka językowa w szerokim rozumieniu oznacza nie tylko system działań ukierunkowanych na wspieranie jednego (lub kilku) języków i odpowiednio nie-wspierania, czyli marginalizowania, a niekiedy i zakazywania innych języków. Polityka językowa oznacza także wybór takiego, a nie innego standardu języka (lub języków) narodowego, udoskonalanie zasad pisowni, wydawanie słowników, omawianie i wprowadzanie nowych terminów, naukę i stosowanie języków obcych, thumaczenie literatury pięknej i naukowo-technicznej, dokumentacji prawnej itd. $Z$ tego względu nawet monoetniczne i jednojęzyczne kraje, które w dzisiejszym świecie raczej należą do rzadkości, również realizują pewną politykę językową - niezależnie od tego, czy nazywają swoje działania (lub brak działań) polityka" (Riabczuk, 2015, pp. 304-305). 
those adopted in, e.g. multilingual countries of Western Europe, the United States or Canada. Ukrainian language policy appears to him as not only an instrument to protect the rights of individuals, but also to highlight the post-colonial nature of the Ukrainian society. This awareness, however, as it can be assumed, would - according to Riabchuk - bring results in the form of opposition to the Creole Ukrainian elites. These elites, he argues, still try to limit the development and protection of cultural determinants of the consistently Ukrainian culture. In his opinion, the situation is dramatic. Beating the alarm, he even states that in the conditions of "undeclared war and patriotic mobilization, signals coming from the Ukrainian-language camp that the Russification of public and media space is progressing, that the provisions of the Constitution and relevant laws providing for mandatory knowledge and use of the Ukrainian language by all state officials are systematically ignored, and that Ukraine is turning into yet another variant of Russia, although one respecting peace more and more liberal, remain almost imperceptible. Thus, as the critics say, it consolidates and legitimizes as a Creole Russian-speaking state with a marginal place for Ukrainian-Aborigines." ${ }^{30}$

Riabchuk strengthens his argument by outlining theoretical views on the nature and functions of language. He observes that on the one hand, it has long been shown that language is not a neutral communication tool. According to him, the fact of which language someone speaks determines what kind of person he or she is. At the same time, each of the existing languages brings a unique vision of the world, so it requires protection and deserves it. This protection is sometimes necessary, since languages do not exist and do not develop in a vacuum, but next to other languages. Hence languages are more expansive because giving, e.g. access to better social roles and greater opportunities for personal development, may be and often is a mortal danger for languages that are on the defensive. In this case - there is no doubt in the view of Riabchuk - a weaker language should be supported, also legally, in an attempt to save in this way a part of the cultural heritage and the heritage of humanity. Finally, in his opinion, we should remember that languages are sometimes used as a tool of governance, social fragmentation, creating artificial hierarchy and doing harm. In his opinion, a well-designed language policy should also oppose this. Through such policies and their influence, the unmasking of linguistic injustice and compensation for language damages should supposedly take place (Riabczuk, 2015, pp. 308, 313).

It ought to be remembered - Riabchuk asserts - that in Ukraine the Russian language has for a long time destroyed the Ukrainian language. For this reason, Ukraine cannot afford a policy of specific language laissez-faire, which in practice would mean legally sanctioned bilingualism, two state languages - Ukrainian and Russian. But in the meantime, "the term of official bilingualism (or two official languages) is in this context only

${ }^{30}$ In Polish: "niewypowiedzianej wojny i patriotycznej mobilizacji - prawie niezauważalne zostają sygnały dochodzące z ukraińskojęzycznego obozu o tym, że rusyfikacja przestrzeni publicznej wraz $\mathrm{z}$ medialną postępuje w dalszym ciągu, że przepisy Konstytucji oraz odpowiednich ustaw stanowiące o obowiązkowej znajomości i wykorzystywaniu języka ukraińskiego przez wszystkich urzędników państwowych są systematycznie ignorowane i że Ukraina przeistacza się w jeszcze jeden wariant Rosji, tyle tylko, że bardziej szanujący pokój i bardziej liberalny. Czyli, jak powiadają krytycy, utwierdza się ona i legitymizuje, jako kreolskie rosyjskojęzyczne państwo z marginalnym miejscem dla ukraińskojęzycznych aborygenów" (Riabczuk, 2015, p. 303). 
an attempt to legally sanction postcolonial normality (actual domination of the Russian language and the Russian oligarchy) and to prevent their institutional revision by legal means." 31 Additionally, according to Riabchuk, "[i]t is symptomatic that none of those fighting for bilingualism in Ukraine take the trouble to explain to concerned opponents how they plan to prevent the Belarusian (or Soviet) scenario of functioning of the two allegedly equal languages, one of which (and it is easy to guess which one), in practice, will prove to be more equal." 32

Thus, when reading the analyzed text, it is difficult to ignore the impression that the author expects that the language policy preventing legal sanctioning of bilingualism will perform two functions. Firstly, it will enable the protection and promotion of the Ukrainian language, which has been ravaged for a long time. Secondly, this policy can sharpen judgment on the socio-political situation in Ukraine, as in its light the postcolonial condition of the country and the central socio-political division determining the dynamics of conflicts taking place therein supposedly become more visible. In other words, as already mentioned, according to Riabchuk, Ukrainian society is still divided primarily into the privileged elite of Creoles and underprivileged indigenous people. The interests of these groups are contradictory, and the controversy about bilingualism in Ukraine is supposed to be a perfect illustration as if the best proof for this theory. The author himself puts this issue as follows: "postcolonial specificity in Ukraine is determined by the socio-economic domination of the Creole oligarchy, which reinforces the domination by using appropriate discourse (including in the sphere of language and culture), stressing the normality of the post-colonial status quo and effectively discrediting contra-discourse attempts of the natives to problematize and deconstruct this normality abnormal for them." ${ }^{\prime 3}$

\section{Conclusions}

Based on the above analysis, some cautious conclusions may be proposed. These should not be seen as statements conclusive with regard to some general issues. The theses discussed below allow rather focus research attention on certain phenomena occurring in the post-Soviet space, especially in Russia and Ukraine. These phenomena seem

${ }^{31}$ In Polish: "hasło oficjalnej dwujęzyczności (czy dwóch języków urzędowych) jest w tym kontekście jedynie próbą prawnego usankcjonowania postkolonialnej normalności (faktycznej dominacji języka rosyjskiego i rosyjskojęzycznej oligarchii) oraz uniemożliwienia ich instytucjonalnej rewizji na drodze prawnej" (Riabczuk, 2015, p. 314).

${ }_{32}$ In Polish: "Symptomatyczne, że nikt z walczących o dwujęzyczność na Ukrainie nie zadaje sobie kłopotu, by wyjaśnić zaniepokojonym oponentom, w jaki sposób planują oni uniknąć białoruskiego (czy sowieckiego) scenariusza funkcjonowania dwóch rzekomo równoprawnych języków, z których jeden (łatwo domyślić się który) w praktyce okaże się równiejszy" (Riabczuk, 2015, p. 314; see also: Vasilevich, 2015, pp. 211-231).

${ }^{33}$ In Polish: "postkolonialna specyfika na Ukrainie determinowana jest przez społeczno-gospodarczą dominację kreolskiej oligarchii, która wzmacnia tę dominację poprzez stosowanie odpowiednich dyskursów (w tym w sferze językowo-kulturowej), akcentujących normalność postkolonialnego status quo i skutecznie dyskredytujących kontrdyskursywne próby tubylców, by tę nienormalną dla nich normalność problematyzować i dekonstruować" (Riabczuk, 2015, p. 314). 
to be symptomatic in the sense that in their light rhetorical dimensions of the post-Soviet language policies are to some extent revealed.

First of all, the thesis that language policies remain in the post-Soviet region as an essential tool for creating one's own and someone else's image seems right. Speaking of them, various entities characterize, more or less accurately or fairly, systems of values shared by themselves and others. Moreover, these policies seem highly rhetorical, focused on the needs of audiences to whom the message is addressed.

The most frequently cited arguments in favor of a specific language policy present in the post-Soviet space can be generally divided into two groups:

1) a given language policy is the right one since it serves the interests of the political community pursuing it; it provides security, order, law, and justice;

2) a given language policy is the right one since it is based on the principle of respecting and protecting the rights of individuals in dealing with the state apparatus and its representatives.

It seems that both arguments are widely approved by post-Soviet societies and hence evaluated as rhetorically strong. For this reason, there are a lot of people willing to use both types of justifications. It is, therefore about convincing people that the promoted language policy is aimed at balancing the interests of both the community and the interests of individuals.

Moreover, one may risk a careful claim that in the post-Soviet space, within the framework of discourse regarding language policies, their creators devote much attention to the issues of instability and threats, stressing the need to protect a specific language or languages. The language sphere appears to them as sometimes strongly conflictual; it happens that they position languages in an antagonistic way, showing, e.g. that the Ukrainian language is being replaced by the Russian language.

However, there is also a narrative, in which the language policy is not only defensive. It is frequently emphasized that investment in the teaching of the state or native language brings tangible benefits and is a kind of opportunity. Moreover, the languages to be protected are very clearly affirmed, sometimes even worshipped.

Implementers of language policies in the post-Soviet regions undoubtedly do not conceal their polemical character. Thus, especially in the comments on various solutions applicable to language issues, own proposals are positioned to others. Large social groups are genuinely interested in how the authorities of the post-Soviet countries treat language questions. Therefore, the issue remains politicized; politicians are eager to use it, comparing with other policies.

Language pluralism is not seen as something inherently right or wrong. Attention is given to both the opportunities created by the co-existence of many languages side by side and related threats. In principle, however, there is no serious talk about a qualitative enrichment of all languages, which would happen in the process of their mutual influence.

It seems that the creators of language policies in the post-Soviet region treat languages as separate systems, within expressly set or at least settable limits. Little is said about dim contours of languages as well as their mutual relations. Borrowings are often approached as something problematic and not as a natural process that can lead to the expansion of the language resources and measures of expression. 
The approach treating languages as points of reference to each other is disregarded. There is also no in-depth discussion on the benefits of the art of translation, propositions to introduce a wide practice of translating texts for school education are rare. Little attention is paid to the highly significant but also sensitive issue expressed, for example, by Goethe in his famous quotation: "He who does not know foreign languages knows nothing of his own" (Wer fremde Sprachen nicht kennt, weiß nichts von seiner eigenen; Goethe, 1907). In the post-Soviet discourses on language policies, it is difficult to find a sound belief that learning foreign languages is an investment in one's own language. Perhaps this is because nowadays these issues seem to be too complicated and their implementation utopian? Perhaps this is so also because spreading a belief in their importance requires an intensive action of many people? Perhaps this is one of the crucial persuasive tasks in the twenty-first century.

\section{References}

Aristot. Rh. 1.2.1. Aristotle in 23 Volumes, vol. 22, translated by J. H. Freese, Aristotle, CambridgeLondon, Harvard University Press, William Heinemann Ltd. 1926, The Annenberg CPB/ Project, http://www.perseus.tufts.edu/hopper/text?doc=Perseus\%3Atext\%3A1999.01.0060\%3 Abook\%3D1\%3Achapter\%3D2\%3Asection\%3D1.

Burke K. (1969), Rhetoric of Motives, University of California Press, Berkeley-Los Angeles-London.

Cardinal L., Sonntag S. K. (2015), State Traditions and Language Regimes. Conceptualizing Language Policy Choices, in: State Traditions and Language Regimes, eds. L. Cardinal, S. K. Sonntag, McGill-Queen's Press, Montreal \& Kingston, London-Ithaca.

Cywiński B. (2013), Szańce kultur. Szkice z dziejów narodów Europy Wschodniej, Centrum Europejskie Natolin, Warszawa.

Goethe J. W. (1907), Maximen und Reflexionen. Aphorismen und Aufzeichnungen, Nach den Handschriften des Goethe- und Schiller-Archivs hg. von Max Hecker, Verlag der Goethe-Gesellschaft, Weimar. Aus Kunst und Altertum, 3. Bandes 1. Heft, 1821.

Isaacs R., Polese A. (eds.) (2016), Nation-Building and Identity in the Post-Soviet Space: New Tools and Approaches, Routledge, London-New York.

Kupidura R. (2015), Demokracja a język. Dyskusja wokót „Ustawy językowej” na Ukrainie, in: Dyskurs postkolonialny we współczesnej literaturze i kulturze Europy Środkowo-Wschodniej. Polska, Ukraina, Węry, Stowacja, ed. B. Bakuła, Poznań.

Lausberg H. (1998), Handbook of Literary Rhetoric A Foundation for Literary Study, Foreword by G. A. Kennedy, Translated by M. T. Bliss, A. Jansen, D. E. Orton, Edited by D. E. Orton, R. D. Anderson, Brill-Leiden-Boston-Köln.

Lichański J. Z. (2007), Retoryka: Historia - Teoria - Praktyka, vols. 1-2, Warszawa.

Perelman Ch. (2002), Imperium retoryki. Retoryka i argumentacja, PWN, Warszawa.

Riabczuk M. (2015), Polityka językowa na Ukrainie: minione debaty i przyszłe rozwiąania, in: Dyskurs postkolonialny we wspótczesnej literaturze i kulturze Europy Środkowo-Wschodniej. Polska, Ukraina, Węgry, Stowacja, ed. B. Bakuła, Poznań.

Shiffman H. F. (1998), Linguistic Culture and Language Policy, Routledge, London-New York.

Vasilevich H. (2015), Linguistic Rights in Belarus: Law and Practice, in: Integration and Exclusion. Linguistic Rights of National Minorities in Europe, ed. E. Kuzborska, Artprint, Vilnius.

Volkmann R. (1995), Wprowadzenie do retoryki Greków i Rzymian, Wydawnictwo DiG, Warszawa.

Worthington I. (ed.) (2010), A Companion to Greek Rhetoric, Malden-Oxford-Chichester. 
Ziomek J. (1990), Retoryka opisowa, Ossolineum, Wrocław-Warszawa-Kraków.

Марусик Т., Державна мовна політика в Україні останнього десятиліття, http://universum.lviv. ua/journal/2015/2/marusyk.htm.

Отношение к статусу русского языка в Украине (пресс-релиз подготовлен Дарыной Пироговой)//КМИС, 10.04.2015.

Празаускас А. (1992), СНГ как постколониальное пространство, "Независимая газета".

Совместное заседание Совета по межнациональным отномениям и Совета по русскому языку, 19 мая 2015 года, http://kremlin.ru/events/president/news/49491.

\section{Polityki językowe jako instrument ksztaltowania i retoryzacji stosunków wzajemnych w regionie postradzieckim}

\section{Streszczenie}

Obszar postradziecki zamieszkują wspólnoty posługujące się wielką liczbą języków i dialektów. Mozaika językowa regionu kształtowała się przez tysiąclecia. Częstokroć stanowiła czynnik poważnie oddziałujący na rozwój sytuacji geopolitycznej w tejże części globu.

Obszar postradziecki pozostaje przestrzenią, w której kwestie językowe nadal jawią się jako wyzwanie. W sporym stopniu tradycyjne problemy uległy komplikacji w okresie regionalnej ekspansji ruszczyzny w wiekach XIX oraz XX. Aktualnie państwa regionu starają się prowadzić bardziej lub mniej autonomiczne polityki językowe, niekiedy obliczone na łagodzenie, niekiedy na zaostrzanie miejscowych konfliktów socjopolitycznych. Polityki te nierzadko okazują się instrumentem, przy pomocy którego gracze regionalni usiłują niwelować tudzież zwiększać rozdźwięki w stosunkach wzajemnych. Co więcej, rozwiązania polityczne w kwestiach językowych często służą jako argumenty w rywalizacji aksjologicznej pomiędzy wspólnotami zamieszkującymi przestrzeń byłego ZSRR.

Celem tekstu jest analiza wybranych aspektów wspomnianych polityk. Stanowi on także próbę ogólnej charakterystyki ich właściwości retorycznych oraz potencjału argumentacyjnego.

Słowa kluczowe: polityka językowa, aspekty retoryczne polityki językowej, obszar postradziecki, specyfika polityk językowych obszaru postradzieckiego 
